\title{
Studi Eksperimen Pengaruh Temperatur Dan Viskositas Pelumas Terhadap Performa Kendaraan Transmisi Manual (Honda Sonic 150R)
}

\author{
Ladrian Rohmi Abdi Syahdanni dan I Nyoman Sutantra \\ Departemen Teknik Mesin, Fakultas Teknologi Industri, Institut Teknologi Sepuluh Nopember (ITS) \\ e-mail: tantra@me.its.ac.id
}

\begin{abstract}
Abstrak-Perkembangan dunia otomotif khususnya sepeda motor terus dikembangkan untuk mendapatkan kenyamanan dalam pengendalian. Produsen otomotif khususnya roda dua (sepeda motor) telah memproduksi kendaraan berkapasitas besar. Para produsen berlomba-lomba untuk menciptakan kendaraan dengan performa dan akselerasi yang baik. Akselerasi dan performa yang baik salah satunya dipengaruhi oleh pelumas. Dengan banyaknya variasi jenis pelumas yang dijual di pasaran memiliki nilai viskositas dan bahan pembuatan pelumas yang berbeda, mengindikasikan bahwa pemilihan pelumas yang sesuai dapat memperbaiki performa kendaraan standart. Pelaksanaan eksperimen ini dilakukan menggunakan chassis dynamometer atau yang dikenal sebagai dynotest. Menggunakan tiga variasi jenis pelumas dimana tiap pelumas dilakukan sebanyak 30 kali running dynotest secara nonstop. Pada penelitian ini didapatkan bahwa setiap variasi pelumas memiliki performa dan viskositas kinematik yang berbeda. Pelumas semi sintetik (Oli 1) pada rpm engine rendah mampu menghasilkan performa yang paling tinggi. Pelumas sintetik (Oli 3) menghasilkan performa paling tinggi pada rpm engine tinggi. Pelumas sintetik (Oli 2 dan Oli 3) memiliki performa maksimum yang lebih tinggi dibandingkan pelumas semi sintetik (Oli 1). Pelumas sintetik (Oli 2 dan Oli 3) memiliki karakteristik viskositas yang lebih baik karena memiliki presentase angka penurunan viskositas kinematik terhadap temperatur yang lebih rendah dibanding pelumas semi sintetik (Oli 1).
\end{abstract}

Kata Kunci- Gaya Dorong, Power, Temperatur, Torsi, Viskositas.

\section{PENDAHULUAN}

$\mathrm{B}$ anyak produsen kendaraan bermotor membuat kendaraan bertenaga tinggi untuk dipasarkan. Saat ini motor dengan transmisi manual banyak diminati oleh masyarakat. Salah satu unsur yang berperan agar kendaraan mempunyai performa yang baik adalah pelumas. Pelumasan sangat diperlukan untuk memperkecil keausan, memperkecil timbulnya panas dan pemuaian, sebagai media pendinginan dan untuk menjaga kebersihan dari mesin. Salah satu hal yang perlu diperhatikan tentang pelumas adalah viskositasnya (kekentalan). Viskositas dari pelumas bervariasi dengan perubahan temperatur. Diketahui bahwa unjuk kerja dan keawetan mesin sangat ditentukan oleh kualitas pelumas. Atas dasar itulah studi ini disusun agar dapat mengetahui pengaruh pelumas terhadap performa pada kendaraan Honda Sonic 150R

\section{URAIAN PENELITIAN}

\section{A. Gaya Dorong Kendaraan}

Untuk menggerakkan kendaraan dibutuhkan gaya dorong untuk melawan seluruh hambatan pada kendaraan. Gaya dorong suatu kendaran terjadi pada roda penggerak kendaraan. Gaya dorong ini ditransformasikan dari torsi mesin kendaraan ke roda penggerak yang terdiri dari kopling, transmisi gigi, gigi diferensial, dan poros penggerak. secara ideal kebutuhan gaya dorong dapat ditunjukkan seperti gambar 1.

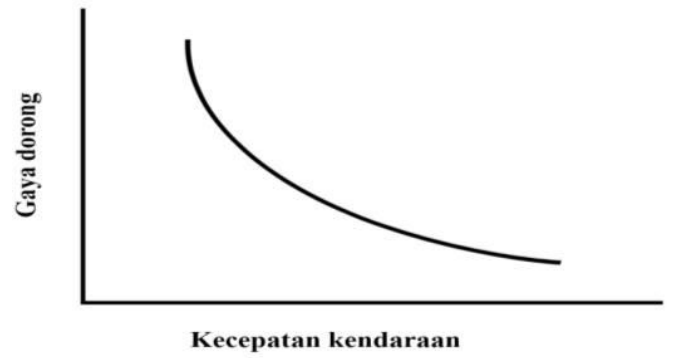

Gambar 1. Gaya Dorong yang Dibutuhkan Kendaraan [1].

Gaya dorong kendaraan didefinisikan sebagai kemampuan kendaraan untuk dipercepat dan mengatasi hambatanhambatan yang terjadi. Diantaranya hambatan rolling ban dan hambatan aerodinamis. Kemampuan kendaraan tersebut sangat dipengaruhi oleh kemampuan mesin kendaraan dan pemilihan tingkat serta rasio transmisi. Secara free body diagram gaya-gaya tersebut ditunjukkan pada gambar 2. Gaya dorong kendaraan $(F t)$ dirumuskan persamaan 1 dan rasio transmisi (it) pada persamaan 2.

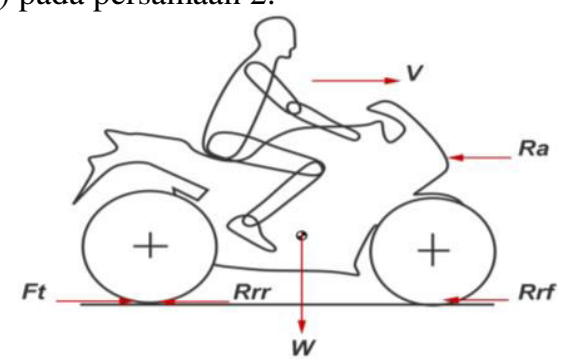

Gambar 2. FBD Gaya Dorong, Kecepatan dan Gaya Hambat kendaraan [2].

$$
\begin{aligned}
& F t=\frac{T e . i t . i g}{r} \eta t \\
& i t=\frac{n e}{n t r}
\end{aligned}
$$

dimana:

Te : Torsi engine 
Ig : Rasio gear

$\eta t$ : Efisiensi transmisi kendaraan

$\mathrm{r}$ : Radius ban kendaraan

ntr : Putaran transmisi

Dari karakteristik torsi engine (Te), terlihat bahwa torsi sebagai fungsi dari putaran mesin. Putaran dari mesin menentukan kecepatan. Hubungan kecepatan kendaraan $(v)$ dan putaran mesin dapat dirumuskan pada persamaan 3 .

$$
v=\frac{n e .2 \pi \cdot r}{\text { it.ig.60 }}(1-\mathrm{S})
$$

dimana:

ne : Kecepatan putar mesin (rpm)

$\mathrm{S}$ : Slip pada ban kendaraan (2-5\%)

\section{B. Aerodynamic Resistance}

Aerodynamic resistance adalah gaya hambat berlawanan arah dengan kendaraan secara horizontal pada kecepatan tertentu. Nilai gaya hambat ini dipengaruhi oleh koefisien drag $(C d)$, densitas udara $(\rho)$, kecepatan kendaraan dan luas frontal kendaraan $(A f)$. Dirumuskan persamaan 4.

$$
R a=\frac{1}{2} \cdot \rho \cdot C d \cdot A f \cdot v^{2}
$$

Tabel 1.

Koefisien drag untuk kendaraan [1]

\begin{tabular}{lc}
\hline \multicolumn{2}{c}{ Jenis kendaraan } \\
\hline Kendaraan penumpang & Koefisien Hambat \\
Kendaraan convertible & $0,3-0,6$ \\
Kendaraan balap & $0,4-0,65$ \\
Bus & $0,25-0,3$ \\
Truck & $0,6-0,7$ \\
Tractor - Trailer & $0,8-1,0$ \\
Sepeda motor + pengendara & $0,8-1,3$ \\
\hline \hline
\end{tabular}

\section{Chassis Dynamometer}

Dinamometer adalah suatu alat yang digunakan untuk mengukur torsi (torque) dan kecepatan putar engine (rpm) dari tenaga yang diproduksi oleh suatu mesin. Dinamometer yang mengukur tenaga putar dan power secara langsung dari unit pemindah tenaga kendaraan, secara langsung roda penggerak disebut chassis dynamometer. Dalam studi ini digunakan chassis dynamometer pada gambar 3. Pada pengujian chassis dynamometer didapatkan nilai engine torque, engine power dan engine rpm.
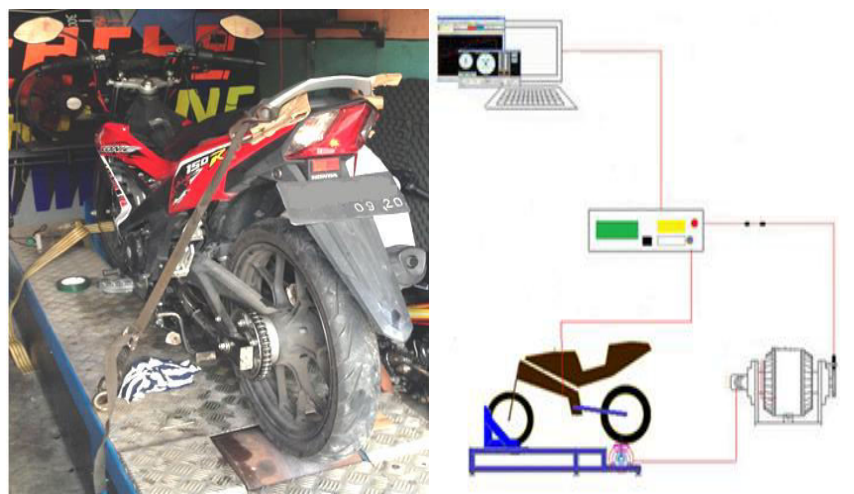

Gambar 3. Skema pengujian kendaraan.

\section{Viskositas Pelumas}

Dalam pembahasan tentang teori dan system pelumasan, salah satu hal yang perlu diperhatikan adalah adanya efek dari dalam minyak pelumas itu sendiri yang disebut viskositas. Viskositas pada suatu minyak pelumas akan menurun dengan kenaikan temperatur, karena melemahnya ikatan molekulmolekul fluida tersebut.

Sesuai dengan Hukum Newton, tegangan geser $(\tau)$ berbanding lurus dengan viskositas $(\mu)$ dan perubahan kecepatan $\left(d_{u}\right)$ [8]. Secara matematis dapat ditulis :

$$
\tau=\mu \frac{d u}{d y} \quad \text { dan } \quad \frac{d u}{d y}=\frac{U}{h} \quad \text { dan } \tau=\frac{F}{A}
$$

dimana $: \mathrm{A}=$ luas penampang bidang $\mathrm{A}$, sehingga :

$$
\frac{F}{A}=\mu \frac{U}{h} \text { atau } F=\mu \frac{A \cdot U}{h} \text { atau } \mu=\frac{F \cdot h}{A \cdot U}
$$

dimana $: \mathrm{h}=$ tebal lapisan minyak pelumas

Disamping viskositas absolut $(\mu)$, juga dikenal viskositas kinematik $(v)$, merupakan viskositas absolut $(\mu)$ per satuan massa jenis $(\rho)$. Pada persamaan 7 .

$$
v=\frac{\mu}{\rho}=\frac{\frac{d y n e \cdot \mathrm{sec}}{\mathrm{cm}^{2}}}{\frac{d y n e \cdot \mathrm{sec}^{2}}{\mathrm{~cm}^{4}}}=\frac{\mathrm{cm}^{2}}{\mathrm{sec} .}=\text { stokes }
$$

\section{E. Tipe Pelumasan}

Pada gambar 4. Pelumasan hidrodinamik didefinisikan sebagai suatu sistem pelumasan dimana diantara dua bidang yang saling bergerak aktif dipisahkan oleh lapisan tipis pelumas secara sempurna. Dimana tekanan pada lapisan tipis pelumas dibangkitkan oleh gerakan relatif kedua permukaan itu sendiri sehingga menghasilkan gaya angkat bagi kedua bidang tersebut.

Pelumasan bidang batas (Boundary lubrication) ini terjadi karena tidak dimungkinkannya membentuk lapisan tipis minyak pelumas yang sempurna karena beban yang terlalu besar, penurunan kecepatan dari permukaan yang bergerak, dan pengurangan jumlah pelumas. Pada keadaan ini lapisan tipis yang terjadi hanya dalam ketebalan beberapa ukuran molekul saja.

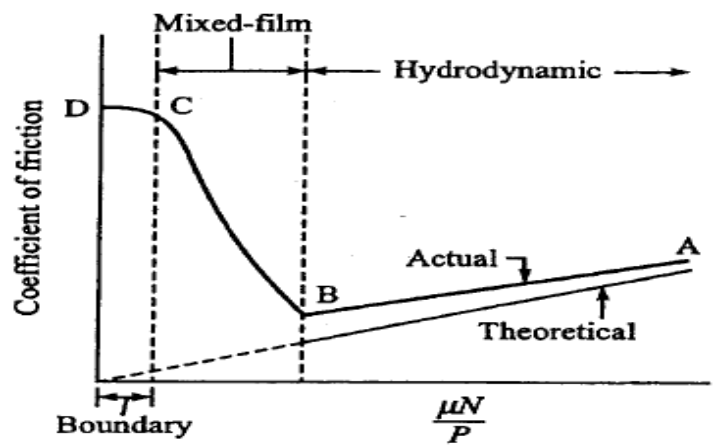

Gambar 4. Hubungan antara coefficient of friction dan daerah pelumasan (Stribeck curve) [3]. 


\section{F. Jenis Minyak Pelumas}

Pelumas mineral merupakan pelumas yang terbuat dari bahan dasar minyak bumi yang diolah dan penambahan zat aditif. Ukuran molekul oli mineral sangat berbeda-beda sehingga menjadikan oli ini banyak mengandung kotoran. Akibatnya daya tahan terhadap panas, oksidasi, gesekan lebih pendek dibandingkan oli sintetik. Pelumas semi sintetik adalah pelumas yang dibuat dengan campuran antara bahan dasar mineral dengan sintetik. Definisi lain menyebutkan pelumas semi sintetik adalah pelumas mineral yang telah diperbaiki sifat-sifatnya mendekati unjuk kerja pelumas sintetik. Pelumas sintetik merupakan oli yang dibuat dari unsur-unsur kimia sintetik seperti poly alpha olefin yang datang dari bagian terbersih dari pemilahan dari oli mineral. Melalui proses kimia dihasilkan molekul dengan ukuran sama yang memiliki indeks viskositas tinggi, stabilitas thermal, ketahanan oksidasi dan kinerja yang optimal. Oleh sebab itu daya tahannya lebih lama.

\section{G. Prosedur Pengujian}

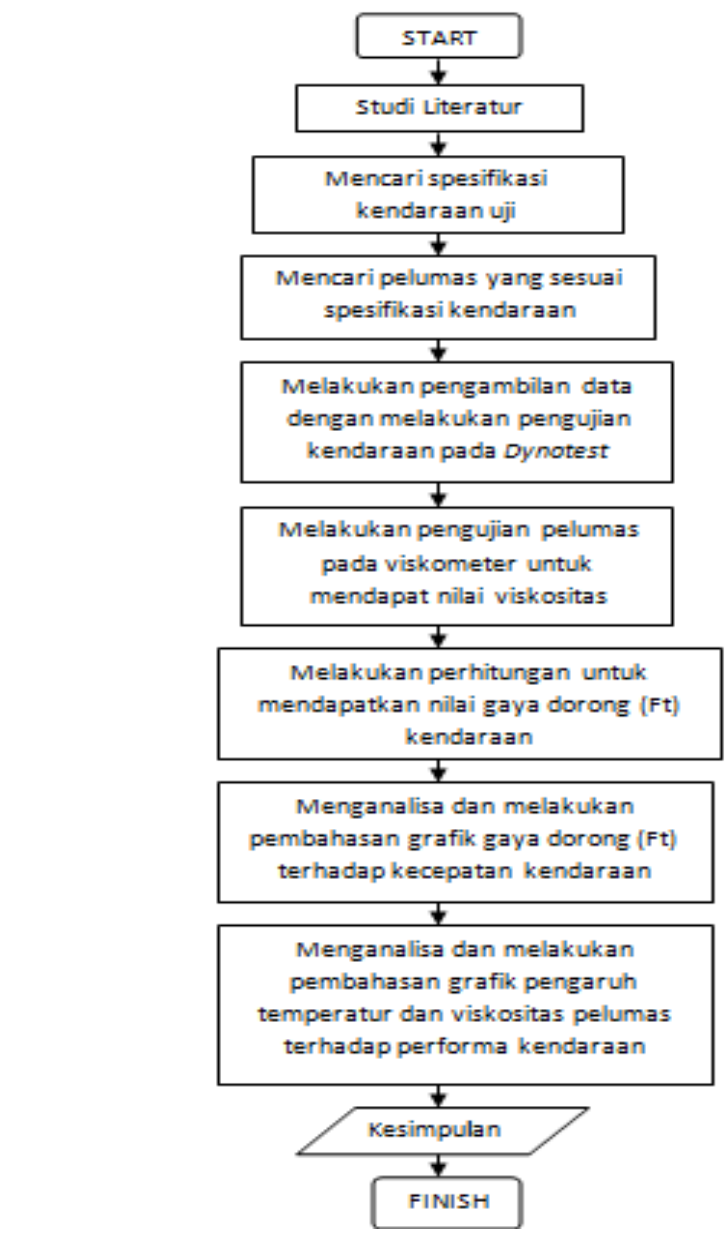

Gambar 5. Diagram Alir Penelitian.

1. Menyiapkan objek penelitian, alat dynotest, dan pelumas engine.

2. Memposisikan kendaraan ke atas dynotest.

3. Menyalakan mesin kendaraan, menunggu hingga pelumasan merata (temperatur pelumas $47^{\circ} \mathrm{C}$ ), memutar handle throttle hingga kemampuan mesin maksimum.
Dilakukan pengulangan 30 kali untuk tiap jenis pelumas. Pengujian kendaraan pada gigi transmisi 4 .

4. Mengukur perubahan temperatur pelumas tiap satu kali running dynotest. Didapatkan temperatur finish pelumas.

5. Mengulangi langkah 1-4 dengan mengganti pelumas lain.

6. Selanjutnya tiap pelumas di uji nilai viskositas pada temperatur start dan finish dynotest.

7. Data torsi engine, power engine dan putaran engine yang dihasilkan ketiga pelumas dapat dilihat pada display alat dynotest.

\section{HASIL DAN PEMBAHASAN}

\section{A. Data Hasil Pengujian Viskositas Kinematik Pelumas}

Pada tabel 3. menunjukkan data hasil pengujian viskositas kinematik pada Lab. Energi LPPM ITS. Ketiga pelumas memiliki viskositas SAE 10W-30 dengan base oil dan zat additiv berbeda. Oli 1 jenis pelumas semi sintetik, Oli 2 dan Oli 3 jenis pelumas sintetik.

Tabel 2.

Data Hasil Uji Viskositas Kinematik Pelumas

\begin{tabular}{|c|c|c|c|}
\hline No & Nama Pelumas & API Service & $\begin{array}{l}\text { Viskositas Kinematik } \\
\text { (LPPM ITS) }\end{array}$ \\
\hline 1. & Oli 1 & API SJ & $\begin{array}{l}\text { Temperatur start } \\
47^{\circ} \mathrm{C}=50,15 \mathrm{cSt} \\
\text { Temperatur finish } \\
96^{\circ} \mathrm{C}=11,44 \mathrm{cSt}\end{array}$ \\
\hline 2. & Oli 2 & API SL & $\begin{array}{l}\text { Temperatur start } \\
47^{\circ} \mathrm{C}=58,30 \mathrm{cSt} \\
\text { Temperatur finish } \\
93^{\circ} \mathrm{C}=14,14 \mathrm{cSt}\end{array}$ \\
\hline 3. & Oli 3 & API SN & $\begin{array}{l}\text { Temperatur start } \\
47^{\circ} \mathrm{C}=57,65 \mathrm{cSt} \\
\text { Temperatur finish } \\
95^{\circ} \mathrm{C}=12,85 \mathrm{cSt}\end{array}$ \\
\hline
\end{tabular}

\section{B. Data Hasil Pengujian Kendaraan}

Data hasil pengujian kendaraan Honda Sonic 150R pada bengkel Iquteche racing, Surabaya. Pengujian tiap jenis pelumas dilakukan 30 kali running dynotest, kemudian di average menggunakan software Sportdyno V3.8. di dapatkan nilai average torsi dan power terhadap rpm engine.
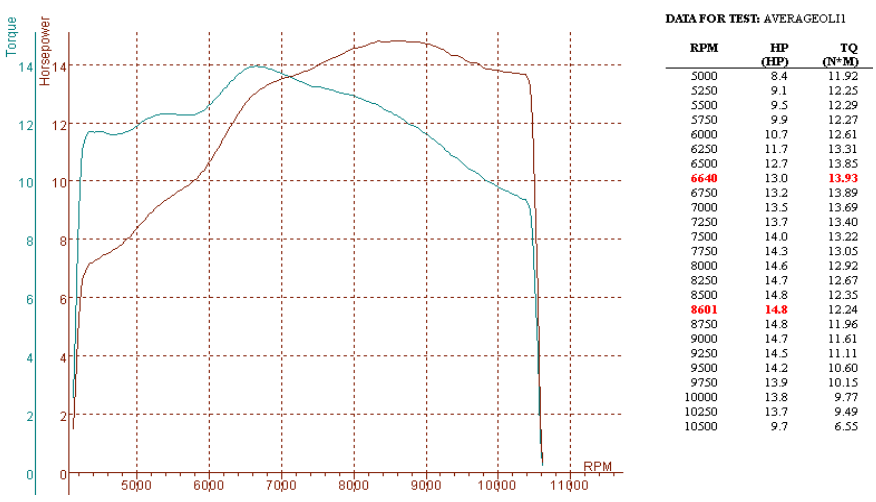

Gambar 6. Hasil average pengujian dynotest kendaraan Oli 1. 


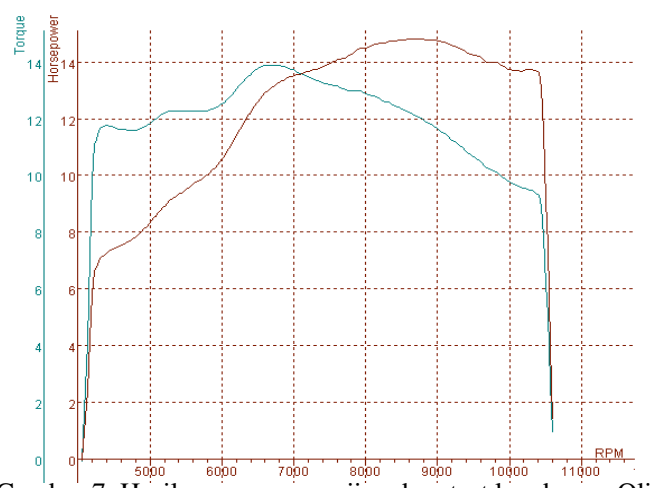

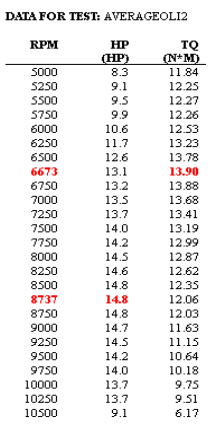

Gambar 7. Hasil average pengujian dynotest kendaraan Oli 2.
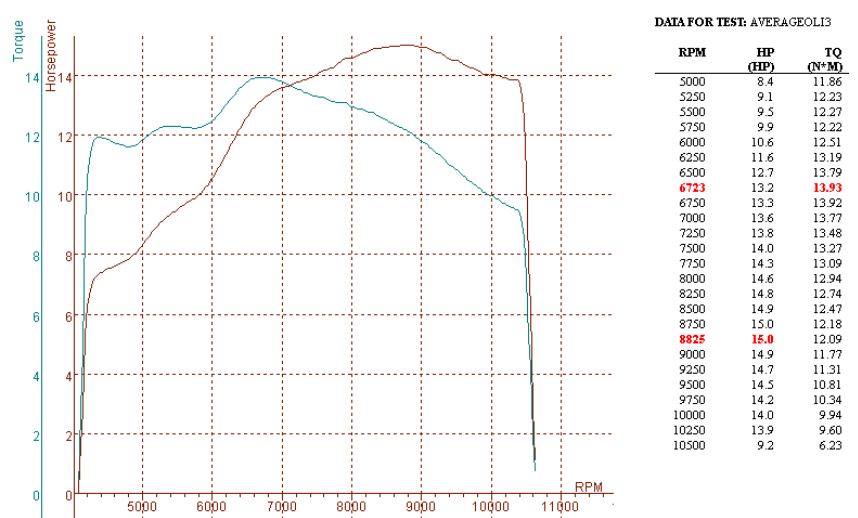

Gambar 8. Hasil average pengujian dynotest kendaraan Oli 3.

\section{Grafik Torsi dengan Rpm Engine Pelumas}
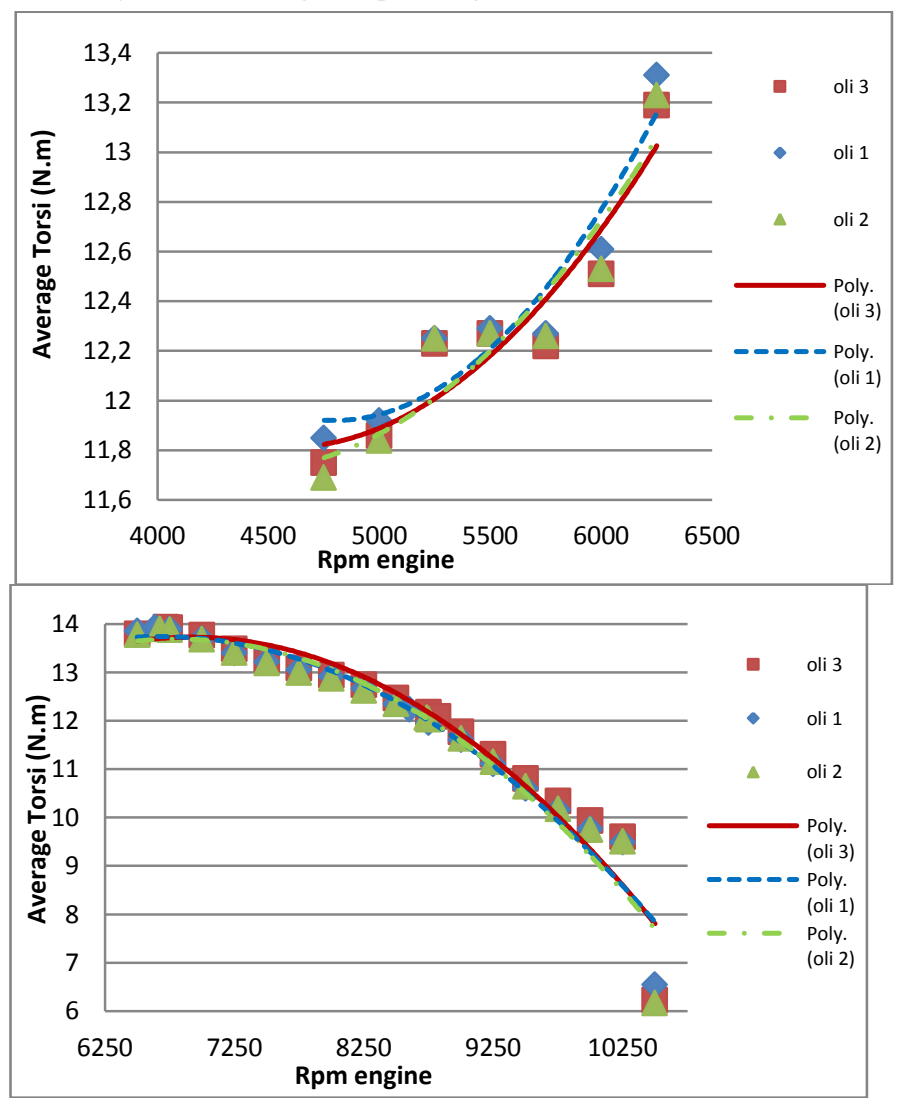

Gambar 9. Grafik perbandingan average torsi engine terhadap variasi pelumas.
Gambar 9. menunjukkan pelumas Oli 3 menghasilkan Torsi maksimal 13,93 N.m, pelumas Oli 2 menghasilkan Torsi maksimal 13,90 N.m dan pelumas Oli 1 menghasilkan Torsi maksimal 13,93 N.m. Viskositas kinematik pelumas akan mempengaruhi nilai torsi engine. Pada high rpm engine, menurut Stribeck curve akan terjadi hydrodinamic lubrication, pelumas dengan viskositas kinematik tinggi menyebabkan friction coefficient besar sehingga torsi engine yang dihasilkan menurun. Oli semi sintetik (Oli 1) pada rpm engine rendah menghasilkan torsi yang paling tinggi karena nilai viskositas kinematik paling rendah. Oli 3 menghasilkan torsi paling tinggi pada rpm engine tinggi karena lebih baik dalam mereduksi friction power yang dihasilkan engine.

\section{Grafik Power dengan Rpm Engine Pelumas}
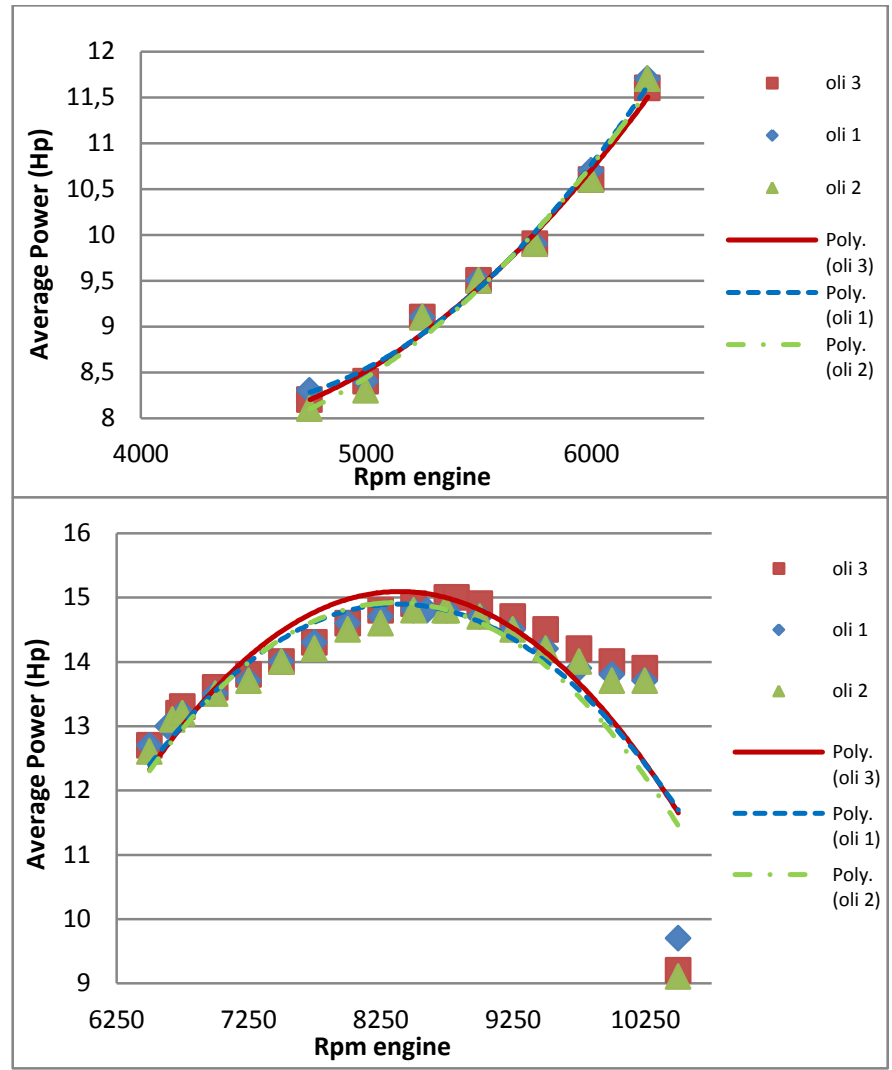

Gambar 10. Grafik perbandingan average power engine terhadap variasi pelumas.

Gambar 10. Menunjukkan pelumas Oli 3 menghasilkan power maksimal $15 \mathrm{HP}$, pelumas Oli 2 menghasilkan power maksimal 14,8 HP dan pelumas Oli 1 menghasilkan power maksimal 14,8 HP. Viskositas kinematik pelumas berpengaruh terhadap power engine. Pelumas dengan nilai viskositas kinematik tinggi akan menghasilkan pengaruh power yang relativ lebih kecil. Pengaruh viskositas kinematik pelumas yang tinggi menyebabkan gaya tahanan terhadap komponen mesin semakin besar, sehingga mengurangi nilai power engine. Oli semi sintetik (Oli 1) pada rpm rendah mampu menghasilkan power yang paling tinggi karena nilai viskositas kinematik paling rendah. Sedangkan pada rpm tinggi (Oli 3) menghasilkan power paling tinggi karena lebih mampu mereduksi friction power. 
E. Perbandingan Gaya Dorong Kendaraan Terhadap Variasi Jenis Pelumas pada Setiap Gigi Transmisi Kendaraan

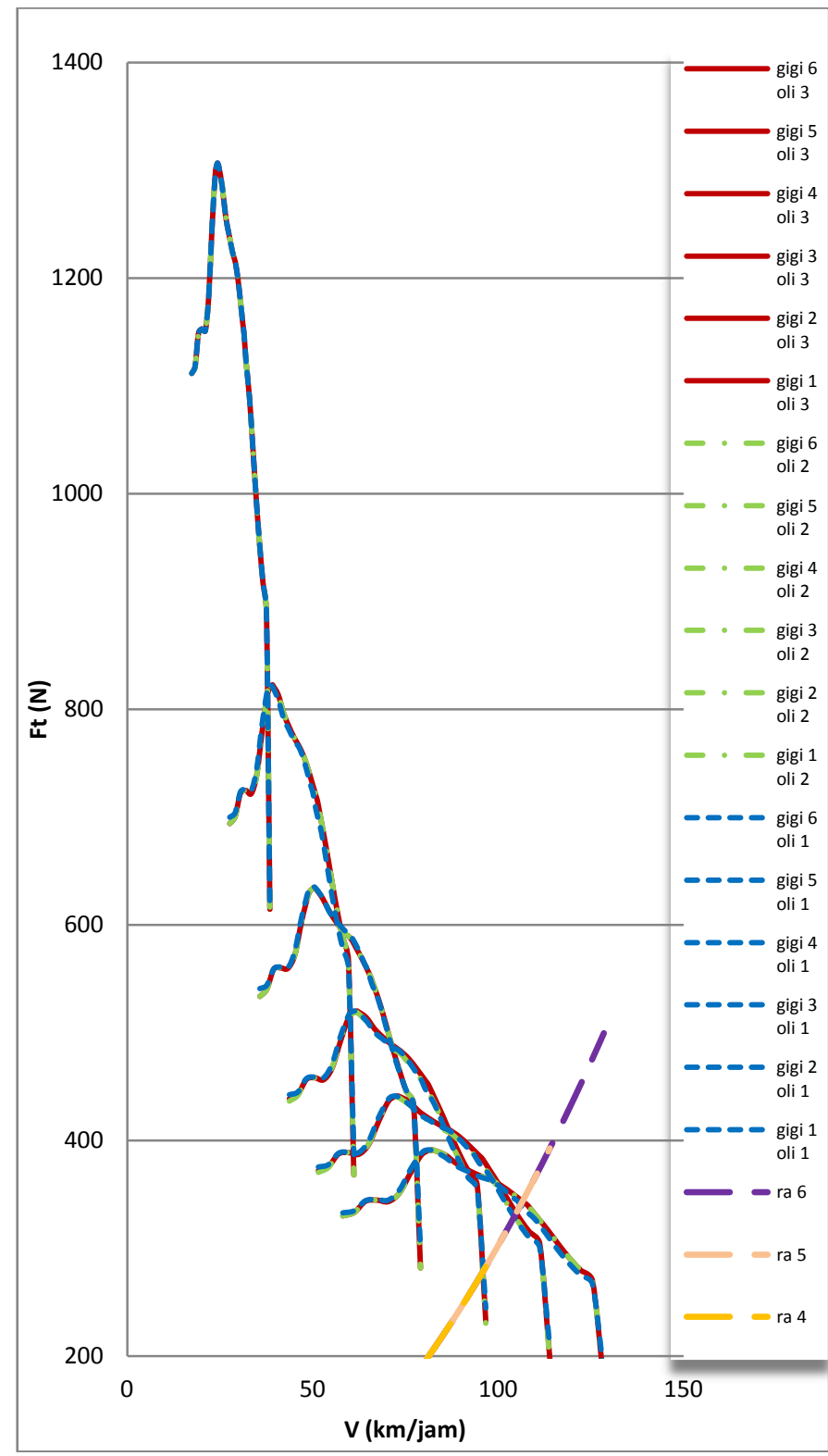

Gambar 11. Grafik perbandingan gaya dorong kendaraan Honda Sonic 150R terhadap tiga variasi jenis pelumas pada setiap gigi transmisi kendaraan.

Gambar 11. menunjukkan perbandingan karakteristik gaya dorong kendaraan terhadap kecepatan. Dimana $F t$ hasil dari persamaan (1) dan V hasil dari persamaan (3). Variasi jenis pelumas berpengaruh terhadap torsi engine. Pada persamaan (6) pelumas dengan $\mu$ rendah akan menyebabkan $\mathrm{F}$ rendah sehingga torsi yang dihasilkan paling tinggi. Karakteristik trendline grafik perbandingan gaya dorong yang dihasilkan ketiga variasi pelumas secara umum adalah sama. Tetapi nilai gaya dorong pada kecepatan tertentu yang dihasilkan oleh masing-masing pelumas tidak sama. Pada persamaan (1) pelumas yang menghasilkan torsi engine paling tinggi akan menghasilkan gaya dorong paling besar.

Gambar 11. berdasarkan grafik tersebut didapatkan pada tiap gigi transmisi, untuk variasi tiga jenis pelumas pada keceparan rendah pelumas (Oli 1) menghasilkan gaya dorong paling tinggi, namun saat kecepatan tinggi pelumas (Oli 3) menghasilkan gaya dorong paling tinggi. Hasil pengujian dynotest merupakan kalkulasi yang telah memperhitungkan gaya hambat rolling. Sehingga gaya hambat yang diperhitungkan hanya aerodynamic resistance. Pada gigi transmisi 4,5 dan 6 nilai aerodynamic resistance maksimal sebesar 282,63 N, 392,66 N, 499,46 N yang didapatkan dari persamaan (4). Kecepatan kendaraan maksimum pada gigi transmisi 1 sebesar 38,5 km/jam, pada gigi $261 \mathrm{~km} / \mathrm{jam}$, pada gigi $379 \mathrm{~km} / \mathrm{jam}$, pada gigi $494 \mathrm{~km} / \mathrm{jam}$, pada gigi 5 $103 \mathrm{~km} / \mathrm{jam}$, dan pada gigi 6 kecepatan kendaraan maksimum sebesar $105 \mathrm{~km} / \mathrm{jam}$.

\section{F. Perbandingan Torsi Engine Maksimum Terhadap Temperatur Pelumas}

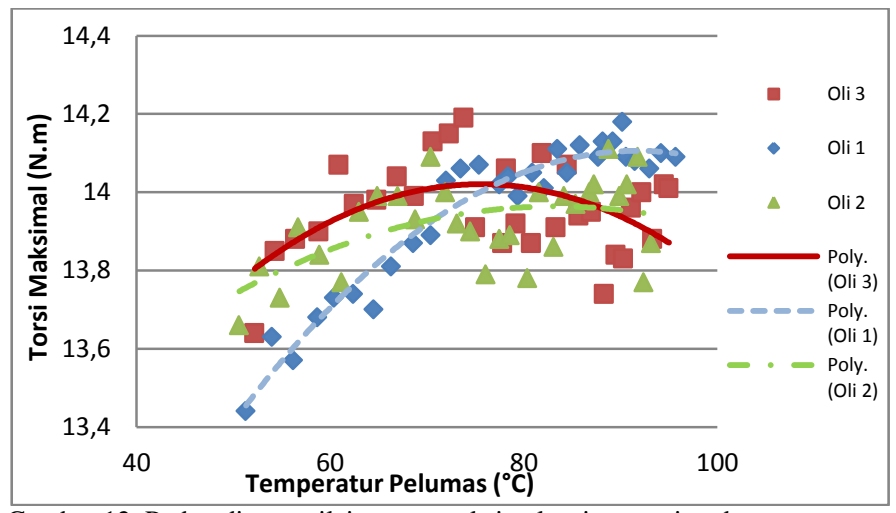

Gambar 12. Perbandingan nilai power maksimal setiap running dynotest terhadap temperatur dari variasi tiga jenis pelumas

Gambar 12. menunjukkan pelumas sintetik (Oli 2 dan Oli 3) memiliki trendline torsi maksimal yang cenderung sama, dimana torsi maksimal tercapai pada temperatur $70^{\circ} \mathrm{C}$. Sedangkan pelumas semi sintetik (Oli 1) memiliki trendline yang terus naik, dimana torsi maksimal terdapat pada temperatur $90^{\circ} \mathrm{C}$. Oli sintetik terbuat dari base oil yang baik dan memiliki molekul yang homogen sehingga tahanan alir lebih baik dan torsi puncak dapat dicapai pada temperatur lebih rendah dengan viskositas kinematik lebih tinggi. Hal ini akan memberikan proteksi yang lebih baik pada engine karena dengan viskositas kinematik yang stabil terhadap perubahan temperatur lapisan film yang terbentuk akan tebal.

\section{G. Perbandingan Power Engine Maksimum Terhadap Temperatur Pelumas}

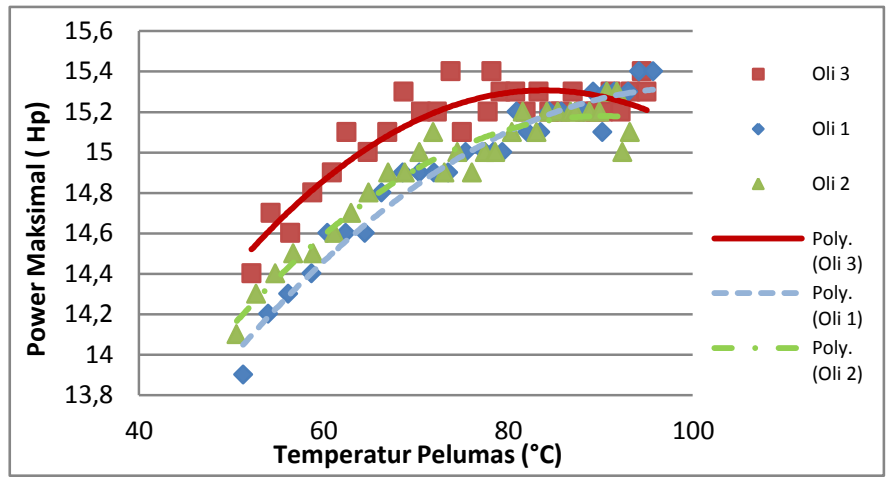

Gambar 13. Perbandingan nilai power maksimal setiap running dynotest terhadap temperatur dari variasi tiga jenis pelumas. 
Gambar 13. menunjukkan pelumas sintetik (Oli 2 dan Oli 3) memiliki trendline power maksimal yang lebih tinggi dibandingkan pelumas semi sintetik (Oli 1). Power maksimal semakin tinggi dengan bertambahnya temperatur ketiga jenis pelumas. Hal ini karena saat temperatur pelumas naik maka viskositas kinematik pelumas akan menurun. Pada temperatur start dynotest $\left(47^{\circ} \mathrm{C}\right)$ hingga $90^{\circ} \mathrm{C}$ pelumas sinteik memiliki trendline power maksimal yang lebih tinggi dibandingkan dengan pelumas semi sintetik. Oli sintetik terbuat dari base oil yang baik dan memiliki molekul yang homogen sehingga tahanan alir lebih baik dan menghasilkan power maksimal yang lebih tinggi. Pada temperatur diatas $90^{\circ} \mathrm{C}$ power maksimal untuk ketiga jenis pelumas cenderung konstan.

H. Perbandingan Perubahan Viskositas Kinematik Pelumas Terhadap Temperatur

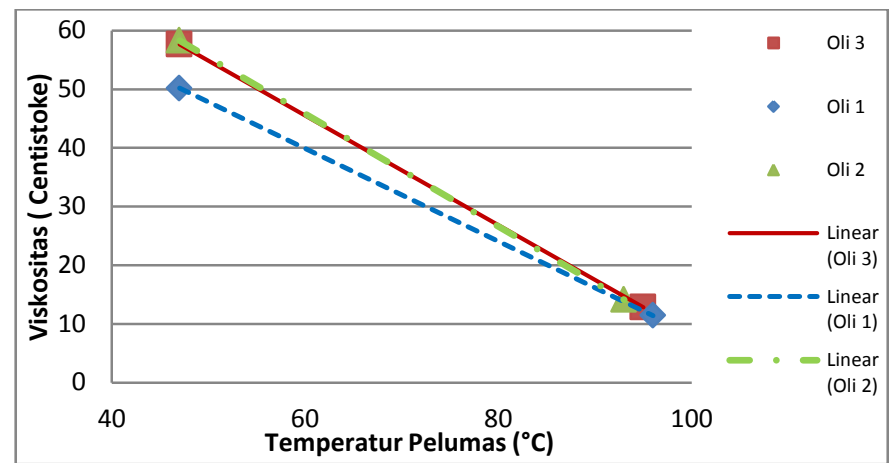

Gambar 14. Perbandingan pengaruh viskositas kinematik pelumas terhadap temperatur pelumas.

Gambar 14. menunjukkan nilai viskositas kinematik dari tiga jenis minyak pelumas mengalami penurunan seiring dengan kenaikan temperatur. Viskositas kinematik (Oli 2) lebih tinggi dari (Oli 3) dan (Oli 1) pada termperatur running dynotest. Pelumas jenis semi sintetik mengalami penurunan viskositas kinematik yang lebih drastis dibandingkan dengan pelumas jenis sintetik. Pelumas sintetik (Oli 2) dan (Oli 3) terlihat tidak mengalami penurunan yang drastis terhadap temperatur.

\section{KESIMPULAN/RINGKASAN}

Semakin rendah viskositas kinematik pelumas akan menghasilkan performa yang lebih tinggi pada Honda Sonic 150R. Pelumas semi sintetik (Oli 1) pada rpm engine rendah mampu menghasilkan performa yang paling tinggi dan cocok untuk penggunaan harian. Pelumas sintetik (Oli 3) menghasilkan performa paling tinggi pada rpm engine tinggi dan cocok untuk penggunaan balap. Pelumas sintetik (Oli 2 dan Oli 3) memiliki performa maksimum yang lebih tinggi terhadap temperatur dibandingkan pelumas semi sintetik (Oli 1). Nilai viskositas kinematik pelumas sintetik (Oli 2 dan Oli 3) lebih tinggi dibanding pelumas semi sintetik (Oli 1). Semakin tinggi temperatur pelumas menyebabkan penurunan viskositas kinematik pelumas. Pelumas sintetik (Oli 2 dan Oli 3) memiliki karakteristik viskositas yang lebih baik karena memiliki presentase angka penurunan viskositas kinematik terhadap temperatur yang lebih rendah dibanding pelumas semi sintetik (Oli 1).

\section{DAFTAR PUSTAKA}

[1] B. Sutantra, I.N. dan Sampurno, Teknologi Otomotif. Surabaya: Guna Widya, 2010.

[2] P. Ramadhan, "Studi Eksperimen Pengaruh Variasi Pegas Kopling Terhadap Gaya Dorong dan Percepatan Pada Kendaraan Yamaha Vixion 150 cc," Surabaya, 2016.

[3] N. Gupta, Fundamentals Of Internal Combustion Engine. New Delhi: PHI Learning Private Limited, 2006. 